\title{
The Korean Nuclear Imbroglio: Can India be a Muted Spectator?
}

\author{
Sitakanta Mishra*
}

\begin{abstract}
The presence of nuclear weapons in North Korea has complicated the strategic scenario in North Asia in general and Korean peninsula in particular. Unless the perceived 'security deficit' with North Korea, due to its nuclear weapons' programme is amicably addressed, especially by reducing America's dominant presence in the region, demanding North Korea's denuclearisation would be unrealistic. Thus, the nuclear imbroglio in Korean Peninsula would endure. The outcomes of the Korean crisis will have serious spillover effects on South and East Asia. As a 'rising' super power, India needs to reflect on her role in the unfolding strategic scene in its extended neighbourhood. This article provides an analysis of the strategic condition India is in and the impact of intervening in nuclear issues involving Super Powers in South and East Asia.
\end{abstract}

Keywords: Nuclear Weapons, Nuclear Deterrence, Nuclear Proliferation, Nuclear Strategy, Denuclearisation, North Korea, Korean Peninsula

\section{Introduction}

The geostrategic imbroglio in the Korean peninsula is the most enduring bout of the Cold War. Seven decades after the Korean War of the 1950s, no tangible peace could be achieved. Caught

* School of Liberal Studies, Pandit Deendayal Petroleum University, Gandhinagar, Gujarat, India; email: Sitakanta.Mishra@sls.pdpu.ac.in 
among powerful demagogues (USA, China, Russia, Japan, and South Korea) with their own conflicting agendas, and Pyongyang's own sense of 'small country' syndrome, the authoritarian regime of Kim Jung-Un took refuge of nuclear deterrence to address the fear of regime ouster. The emergence of nuclear weapons in the region has drastically altered the strategic balance in DPRK's favour but stranded the regional strategic environment at a crossroad. The current strategic "developments in the region have the potential to bring in a fundamental realignment in the [global] balance of power" (Pant, 2018) which may not be of India's liking. An aspiring superpower is supposed to shoulder global responsibilities. Should India, as one aspirant, be a muted spectator? What role should India play in the unfolding power game in North Asia that could lead towards a peaceful settlement?

\section{An Introspection}

After a stretch of shadow boxing between North Korea and America, Pyongyang has opened to the world. The meeting between two Korean leaders in Panmunjom in April 2018 and subsequent summit meeting between the North Korean leader Kim Jong-Un and American President Donald Trump in Singapore in June 2018 have undoubtedly paused the 'game of nerves' as Kim pledged to work towards 'denuclearization' in exchange for guarantee of his regime security (The New York Times, 2018). However, given "North Korea's history of duplicity, broken pledges" (The Crisis Group, 2018) and America's strategic interests and overwhelming presence in the region, Korean strategic theatre still gives a sense of a nightmarish war.

Whatever may be the end result, for the time being, Pyongyang seems to have effectively deterred Washington's fire and furry and stands apart from other fated autocratic regimes like Saddam Hussein in Iraq and Muammar Gaddafi in Libya, who perished for they had no promising nuclear weapons capability. Realistically, the introduction of nuclear weapons in the Korean peninsula, first by the USA and subsequently by North Korea, has left no room for military manoeuvre, turning the regional strategic environment towards a 'balance of terror'. 
A serious concern is the 'domino effect' of nuclear weapons with North Korea in the region and the globe. It would be premature to deduce any conclusion whether South Korea or Japan will opt for the nuclear weapons rout. Countries like UK and France have gone disbelieving America's nuclear umbrella; meanwhile, the world has only one precedent of a complete reversal of nuclear weapons programme - South Africa. Only time will prove if the Korean Peninsula will be allowed to achieve Nuclear Weapons Free Zone (NWFZ) status by withdrawing nuclear umbrella extended by the USA and rolling back of Pyongyang's strategic programme.

Moreover, given the complexity, nothing can be ascertained regarding the freshly initiated inter-Korean and USA-North Korea dialogue. Is the grand bargain of 'denuclearization' by North Korea in return of 'demilitarization' of Korean peninsula the answer to heralding lasting peace in the region? Will the Korean peninsula be nuclear-weapons-free-zone anytime soon? America's current policy of "selective engagement and partial commitment to defend allies" might strengthen the doubt on the reliability of the US security guarantee and extended deterrence. Is the world then going to see more nuclear weapon states soon?

\section{How it Happened}

Arguably, the current Northeast Asian security environment is largely made in USA or result of "America's fault" (Keating, 2017). The root of the problem can be traced back to Cold War, and specifically to the Korean War that ended with an Armistice Agreement but not with a permanent peace agreement in 1953 (Waxman, 2018). As a matter of fact, in violation of the Article II, section 13(d) of the Armistice Agreement, the US installed "more than 1720 nuclear weapons in South Korea making it the biggest nuclear warehouse till the 1980s"(Vaddi, 2018). In addition, the joint military exercises numbering around 40 annually between South Korea and USA troops with nuclear-powered submarines have escalated the military tension in the Korean Peninsula, and strongly perceived by Pyongyang as preparations for a preemptive attack on North Korea (Vaddi, 2018). During the Cold War, the Soviet Union was managing and protecting its satellites including North Korea against US threats. With the disintegration of Soviet 
Union, Pyongyang found to be out of the orbit and resorted to a self-help strategy. It introduced the Songun 'Military First' policy during the 1990s to protect its sovereignty; it is believed that this was the starting-point of North Korea's nuclear ambition (Vaddi, 2018).

Even at the height of the Cold War tensions, the then North Korean leader Kim II-Sung floated the idea of an NWFZ on the Korean peninsula. Nobody heeded to his idea that time; George W. Bush only withdrew all US nuclear weapons from South Korea. This helped in the signing of the 1992 Joint Declaration of the Denuclearization of the Korean Peninsula. But it was realised that South Korea though stationed no American nuclear weapons, it enjoyed extended nuclear umbrella from the USA, making it a crypto nuclear weapon state. Still, Pyongyang concluded the safeguard agreement with the IAEA, following which, nuclear inspection of North Korea's programme started.

Serious tensions arose between the US and North Korea over the issue of the scope and level of nuclear investigation in 1992. Meanwhile, the US carried out Team Spirit joint military exercise with South Korea. Subsequently, the USA stepped up diplomatic efforts and signed an Agreed Framework with North Korea in 1994 under which DPRK agreed to abandon its nuclear weapons ambition in exchange for aid from US, Japan, South Korea through the KEDO project. The US conditionally agreed to provide help for two light water reactors but were intentionally delayed as alleged by DPRK. Post-9/11, US sent negative signals to North Korea by including it in the 'axis of evil' states and listing it in its Nuclear Posture Review of 2002 as a country against which the US should be prepared to use nuclear weapons (Roblin, 2018) and plan for regime change, while stopping fuel oil deliveries. In protest, North Korea withdrew from the Nuclear Non-proliferation Treaty (NPT) in 2003 and that led to the consequent escalation of the Korean imbroglio.

On the other hand, North Korea's provocative actions, rhetoric, and brinkmanship have equally deteriorated the situation inviting stringent sanctions and US-South Korea military assertiveness. There are many reported incidents of North Korean involvement in bomb attacks in South Korea, hijacking of the airline, attempt to kill 
President Park Chung-Hee, attacks on warship near the border, and so forth. A North Korean submarine's torpedo sank a South Korean navy ship on 26 March 2010 causing the deaths of 46 sailors (BBC, 2010). All these have culminated in the current strategic imbroglio in the region which have serious global implications.

\section{Six-Party Talks}

Giving diplomacy a chance to persuade North Korea to roll back its nuclear weapons program, a series of multilateral negotiations involving six parties - China, Japan, North Korea, Russia, South Korea, and the United States (known as 'Six-Party Talks') - were held intermittently since 2003. China hosted and led the talks and arrived at critical breakthroughs in 2005. North Korea pledged to abandon "all nuclear weapons and existing nuclear programs" and return to the NPT and in 2007 the parties agreed on a series of steps to implement that 2005 agreement (Kelsey, 2018). However, all the steps were not fulfilled except the shutting and sealing of the Yongbyon reactor that produced plutonium for its weapons program.

Toward the end of the George W. Bush administration, six-party talks grounded to a halt as North Korea did not agree on specific IAEA verification measures of its nuclear activities. Subsequently, it conducted a satellite launch, believed to be the testing of its ICBM technology defying all international pressure. In 2009, Pyongyang decided to pull out from the six-party process expelling all IAEA inspectors from the country and resumed the nuclear enrichment program in order to boost its nuclear deterrent. The Korean peninsula once again became the hotspot of the world giving a sense of nuclear flash point. After the Cheonan crisis, North Korea conducted an underground nuclear test on May 25, 2009. In November same year another exchange of fire, the Battle of Daecheong took place where North Korea reportedly sustained heavy casualties (Revolvy, 2010). On 23 November 2010, North Korea shelled South Korea's Yeonpyeong Island killing two South Korean soldiers (The Telegraph, 2010).

Amidst all these, China has periodically called for the resumption of the talk process. But only in February 2012, the United States and 
North Korea announced a "leap day" agreement to provide substantial food aid in return for the North agreeing to a moratorium on uranium enrichment and missile testing and a return of IAEA inspectors to Yongbyon, leading to a resumption of the six-party talks (Reuters, 2012). Till 2014, attempts were made to bring North Korea back to the negotiating table but without avail. The six-party talks though aimed to find a peaceful resolution of the conflict in the Korean peninsula, by allaying security fears of North Korea, it did not succeed.

\section{The 'Security Deficit'}

There are compelling reasons why diplomacy has suffered a serious setback with regard to the conflict resolution in the Korean peninsula. The Super Power presence in Korean peninsula especially America's security umbrella over its allies undoubtedly has generated substantial 'security deficit' for others. North Korea's closeness with China is inadequate to balance its adversarial relations with America and South Korea which is an ally of the former. The presence of 70,000 American troops during the late 1950 s in South Korea which has been reduced to 28,000 today is no less threatening. Justifications for the US troop presence is often expressed in the following manner: "the American presence stifles the urge for Seoul to take other, more destabilizing steps to ensure its safety - such as developing nuclear weapons of its own. When the American military appeared to be pulling back from Asia in the 1970s, in fact, South Korea took steps toward building a nuclear arsenal. Since then, there has been a tacit bargain: The U.S. maintains a tangible, visible commitment to South Korea and South Korea foregoes the nuclear weapons it could easily develop. The U.S. troop presence is the key to deterrence and reassurance on the Korean Peninsula, bringing tenuous stability to an important part of the world" (Brands, 2018).

Realistically, the benefits of this arrangement are inherently vague and "counterfactual because they rely on judgments about the bad things that might happen if the U.S. stopped doing what it does" (Brands, 2018). The 'security dilemma' created by the lopsided security management now dictates the regional strategic calculations. Therefore, North Korea proposes to provide the 
Korean Peninsula with a NWFZ which is unacceptable to the USA. It has unambiguously laid out the following conditions or terms under which North Korea would be happy to denuclearise:

1. The US and South Korea should allow international verification that all nuclear weapons previously stationed in South Korea have indeed been removed and remove any weapons that still remain.

2. Guarantee that the US would never again deploy nuclear strike weapons on the Korean Peninsula and its surrounding region.

3. Promise that no nuclear weapons will be used to threaten or attack North Korea.

4. Declare an evacuation of the US army that owns the nuclear usage right in South Korea (Terry, 2018).

More importantly, the precedents of America's interventions in other parts of the world seem to guide the authoritarian regime in North Korea to look for regime survival options desperately. Reliance on China or Russia would not be viable as the USA can influence them at ease. Also, none of these countries would risk annoying Washington in favour of Pyongyang. North Korea's autocratic leader is aware that except nuclear weapons, no amount of conventional weapons build-up can bridge the persisting security deficit. It is not beyond his imagination that if Saddam Hussain had nuclear weapons, America would not have dared to intervene in Iraq. It is gradually unfolding that nuclear weapons with North Korea and its aggressive signalling have effectively deterred America to resort to 'regime change' option. The Trump administration seems to be aware and is working to allay this fear. In an interview with Fox News, US Secretary of State Mike Pompeo said, "We will have to provide security assurances to be sure ....This has been the trade-off that has been pending for 25 years" (The Indian Express, 2018). Even President Trump decided to halt the planned joint military exercises with South Korea arguing that the US will "save a fortune" (Stracqualursi, 2018). 


\section{Regional Strategic Imbroglio}

The inter-Korean rivalry, the involvement of USA, and the presence of nuclear weapons in the Korean peninsula, has sufficient spillover effects on entire North Asia. As North Korea borders China and Russia, any military action on North Korea is bound to affect both. Moreover, the involvement of the USA and its policies have generated concerns for other stakeholders. For example, China opposed to any deployment of nuclear weapons by Japan and South Korea in response to North Korea's capability. The "deployment or development of nuclear weapons in South Korea and Japan will bring them to the door step of China" (The Economic Times, 2017). Also, Beijing firmly opposes deployment of THAAD (Terminal High Altitude Area Defence) system in South Korea by the USA because "its powerful radars could monitor China's movement of missiles and their deployment" (Ibid).

Olly Terry views that China and Russia would support the North Korean demand for NWFZ, and aid in the removal of all military hardware through international verification. But these are "unlikely to be attractive to the US which gains huge strategic advantage from having troops and military hardware" in South Korea. The legitimacy and justification of US presence would also disappear if Korean NWFZ is established and the North Korean threat removed (Terry, 2018).

Another important regional player, "Japan faces an existential crisis" for the nuclear developments in the Korean peninsula. Many Japanese citizens were allegedly abducted by North Korea. Japan, an ally of America that has stationed American troops and enjoys US nuclear umbrella, is an easy target within easy reach of North Korean missiles. In response, Japan follows the international multilateral sanction directives and frozen assets of 103 private companies of North Korea after it's nuclear and missile tests. Tokyo is determined not to relax the sanctions imposed unless until the abduction issue is amicably resolved.

Meanwhile, China has a clear agenda on the Korean peninsula but it is under tremendous pressure to take the lead in brokering peace in the Korean Peninsula. South Korea and the US want China to shut-off the oil pipeline that runs into North Korea under the Yalu 
River "for a couple of months" before the winter, to see if fuel shortages would compel Pyongyang to negotiate (Perlez, 2017). China had to stop the import of coal and iron ore from North Korea and did not export oil products in November. China seems to have consistently and strictly enforced relevant UN Security Council resolutions on North Korea. However, given their ideological proximity and long-standing relationship, it would be difficult to fathom the exact volume of China-North Korea trade that is continuing still. Obviously, China has an upper hand in Korean affairs but with its own agenda and strategic calculations.

Russia, as a neighbour, is equally concerned about the successive launches of ballistic missiles and nuclear test by North Korea. Moscow "attaches great importance to safeguarding the international non-proliferation regime and upholding the goal of a nuclear-free Korean Peninsula." It particularly emphasises that "North Korea's security should also be taken into consideration and North Korea's reasonable concerns should be respected" (Guangcheng, 2017). On the issue of the THAAD system, Russia makes it clear that this move will seriously damage the strategic security interests of the countries in the region, including China and Russia, and will not contribute to achieving the goal of a nuclear-free Korean Peninsula and the peace and stability in the region (Sinha, 2018). "China and Russia have adopted an almost identical stance on the issue of North Korea's nuclear crisis" (Guangcheng, 2017).

Therefore, building consensus between the major stakeholders like China, Russia and Japan to adopt diplomatic options, instead of sanctions and aggressive posture, is inevitable for any security balancing act in the Korean Peninsula. No amount of economic punishment would hold back the 'intent' for nuclear weapons. In addition, the regional grouping ASEAN can contribute and play a constructive role in helping to usher in peace and stability in the Korean peninsula. Since 2000, ASEAN has supplied a venue for dialogue between North Korea and the international community. (Strait Times, 2018) 


\section{Learn to Live with Nuclear}

Nuclearised Korean peninsula is a reality today and its denuclearization is a difficult proposition. The incentive is neither lucrative nor there available a conducive regional environment to expect Pyongyang to adopt a desired path. All concerned must introspect to understand and nurture a regional atmosphere that would automatically facilitate the smooth return of a prodigal son to the nonproliferation regime. The idea of an NWFZ for Korea was never taken seriously by the US. As long as America insists on nothing less than the Complete, Verifiable, Irreversible Disarmament (CVID) of North Korea's nuclear programme, instead of a nuclear weapons-free zone in Korean peninsula without a reciprocal withdrawal of its nuclear umbrella over South Korea, "North Korea is not going to give up any pieces of its deterrent" (Korda, 2018). Whatever promise Pyongyang has made in the Singapore summit recently can be taken back by it later!

Considering the level and magnitude of North Korea's nuclear programme today, even if Pyongyang accedes or succumb to pressure which is unlikely, "the denuclearization process may take up to 15 years to complete in which case even the January 2021 target will be impossible to achieve "( Kan, 2018). North Korea has conducted six nuclear tests so far (2006, 2009, 2013, twice in 2016, and 2017), the last one being claimed as a thermonuclear device. It is speculated that Pyongyang may have 13 to 21 warheads by now. The dismantling of North Korea's entire nuclear weapons infrastructure with multilateral verification process would be a long-drawn process. What is crucial, therefore, is arresting DPRK's 'felt need' and 'intent' for nuclear weapons. Unless the root cause - security deficit - is addressed, there would be no rolling back of its programme. Without addressing insecurity perception, no qualitative change in the Korean strategic environment can be achieved.

Therefore, the options for achieving regional peace in Korea are limited. If America pays a second thought in its strategic interests in the region by reorienting its equations with its allies while assuring non-intervention in North Korea, de-link its strategic presence vis-à-vis China and Russia, then Pyongyang might forgo 
its nuclear brinkmanship; lest, the world has to learn to live with the nuclear North Korea and a nuclearised peace in Korean peninsula. Though 'nuclear myth' (nuclear weapons provides ultimate guarantee of peace) dictates countries to opt for nuclear deterrence, 'nuclear taboo' does not permit to use the bomb as nuclear war cannot be won. Mutual assured destruction (MAD) in a nuclear exchange will make no one a victor or a vanquished. It would be safe to assume that the North Korean leader would pile up a sizable nuclear inventory to acquire sufficient deterrent capability, but not to go down on the path of destruction by resorting to their actual use.

More importantly, the 'domino effect' of nuclear weapons with North Korea would be felt sooner or later in Japan and South Korea which is in no one's interest. Certainly, America is to be blamed for introducing nuclear weapons to the region setting on the proliferation chain. Hypothetically, nuclear weapons capable Japan and South Korea will certainly validate the process of 'decline of America' as the sole superpower, heralding the "post-Western world" order where there would be many 'great powers' instead of superpowers, in a regionalised or defused world order.

\section{India's Stakes}

Though India's stakes in the current Korean crisis are large, New Delhi "does not enjoy much clout in the region compared to other regional players like China and Russia because of its physical distance" (Sajjanhar, 2017). Historically, India had played a "much overlooked but significant role" in bringing the Korean conflict of the 1950s to an end (Ramesh, 2017). Jawaharlal Nehru with support from his aides like B.N. Rau, K.M. Panikkar, V.K. Krishna Menon crafted and successfully executed the peace campaign that resulted in the unanimous adoption of the Indian resolution at the UN. Subsequently "Menon submitted another proposal in 1953 to the UN, which, however, was not acceptable to the Americans who came up with their own version. But they agreed to merge their resolution with Menon's to move things forward. This was then to lead to the Armistice Agreement" (Ibid) of July 1953 that heralded truce, though uneasy, in the region. 
The strategic environment in Korean peninsula during the 1950s and India's role in it cannot be extrapolated to the current scenario in the region. But the strategic developments and outcomes in the region have serious implications for India. The first concern for India would be the difficulty in meeting the China challenge if "any diminution of the US role in Asia" occurs (Objectiveias, 2018). Second, India cannot be a muted spectator of the imminent nuclear proliferation chain in the neighbourhood. If Seoul and Tokyo break out from American nuclear umbrella arrangement and acquire nuclear weapons of their own, Asia would be the most crowded nuclear weapons continent. This scenario is not in the best interest of India which has championed the philosophy of nuclear nonproliferation and disarmament. Third, the North Korean nuclear technology may find a way to Pakistan as a proliferation network thrived between them.

Though India cannot turn a blind eye towards North Korea's belligerence, its space for diplomatic manoeuvre is limited given the intricate rivalry among major powers in the region. Owing to long physical distance and less economic dependency, India's influence on North Korea is low. The volume of trade between the two is small; even though India has been North Korea's second largest trade partner after China (Pant, 2018). India's trade turnover with North Korea was around USD 200 million with exports of USD 111 million and imports of around 90 million in 2016 (Sajjanhar). But bilateral trade has come down drastically since 2016-17 for India's strict adherence to UN sanctions of provisions. India has stopped all trade transactions, especially exports of petroleum products, except for food and medicine supplies. Reportedly, India was one of the few countries in the world that provided technical training for North Korean students at the Centre for Space Science and Technology in Asia and the Pacific (CSSTEAP), Dehradun, even after the UN imposed the first set of sanctions in 2006 (Bhowmick, 2016) which has been refuted by India's MEA as "baseless and without any merit" (Bhattacherjee, 2016). Currently, India's economic transactions with North Korea are abysmal. One major concern that India must take note is that North Korea will be forced to depend more on China. Furthermore, economic sanctions have limited impact on nuclear proliferation behaviour. 
Nevertheless, India has a cordial relationship with every actor in the region giving it a moral and neutral high ground. The United States, therefore, expects India to play an active role in dealing with the Korean nuclear crisis. Admiral Harry Harris, commander of the US Pacific Command, said "...India's voice is a loud voice, that people pay attention to. So, I think that India could help North Korea, perhaps, understand the seriousness by which the United States views that threat" (NDTV, 2017). Harsh V. Pant (2018) says, as India has her own equities to preserve in North Korea, it is for India to decide on what kind of role it wants to play in diffusing the rising tension between the US and North Korea. In the past, despite US pressure, India has refused to reduce its diplomatic engagement with Pyongyang and has not been supportive of UN resolutions. Reportedly, "New Delhi refused a request from U.S. Secretary of State Rex Tillerson to shut down its diplomatic mission in Pyongyang altogether" (The Livemint, 2017). India feels that there is an imperative to maintain a diplomatic presence in North Korea which can be useful for the USA as a channel of communication. India's External Affairs Minister Sushma Swaraj could manage to convince Tillerson of the need for India to maintain a diplomatic presence underlining that "some of their [US] friendly countries should maintain embassies there so that some channels of communication are kept open" (Landay, 2017). This does not mean that India is sympathetic towards North Korea's missile and nuclear ambitions. India has toughened its stand on the nuclear and missile proliferation activities by Pyongyang, and vehemently highlights its linkage with the Pakistan-led proliferation network.

So far India's approach towards the Korean issues has been cautious and pragmatic. By avoiding bandwagoning with the 'pressure campaign' and warmongering provocations by America and her allies, India advocates diplomatic methods for peaceful resolution of the Korean crisis. India can shoulder certain responsibility as an emerging global player, and a stable and peaceful Korean peninsula is in India's best interest. India welcomes Donald Trump's summit meeting initiative with the North Korean leader. In fact, during the meeting between US Secretary of State Rex Tillerson and Canadian counterpart Chrystia Freeland in Ottawa, USA announced India's name as one of the 
important parties along with Republic of Korea, Japan, Sweden, and the Vancouver Group "to discuss North Korea's nuclear threat and ways to improve the effectiveness of the current pressure campaign against the reclusive nation" (PTI, 2017).

As latest step, India's Minister of State for External Affairs General VK Singh paid a two day visit during 15-16 May 2018 to North Korea at the invitation of North Korea to hold talks with several leaders including Foreign Minister Ri Yong Ho on "a range of issues covering political, regional, economic, educational and cultural cooperation between the two countries" (MEA, 2018). According to the MEA statement, "Singh highlighted the threat from nuclear proliferation, in particular, India's concerns in the context of the proliferation linkages with India's neighbourhood. The DPRK side emphasised that as a friendly country, DPRK will never allow any action that would create concerns for India's security" (MEA, 2016). The visit has surprised many for its secrecy and the timing when Pyongyang's threatened to cancel the scheduled talks with US President Donald Trump in Singapore in June 2018.

\section{A Word of Caution}

Any regional conflict involving nuclear weapons are normally protracted having no easy solutions. Given the secluded authoritarian regime in North Korea and its nuclear brinkmanship, the issue is extremely delicate for diplomatic as well as military adventure. History provides no example of the Korean type to draw lessons from. Donald Trump's conciliatory approach looks pragmatic at this juncture even though not much is expected from North Korea in terms of nuclear disarmament. The aspired outcome of global efforts (rollback of North Korea's nuclear weapons programme) would largely depend on the future status of the US military presence in the Korean peninsula; positive equations among China, Russia, USA, Japan, etc. and, Kim's perception of his regime security. The traditional nonproliferation techniques involving pressure campaign through the imposition of economic sanctions, the threat of regime change, military intervention, UN resolutions, and so forth have never worked, and are unlikely to persuade North Korea for a U-turn in her nuclear 
ambitions now. What is needed is an out-of-the-box approach or custom-designed package taking into account the target country's politico-strategic compulsions.

As far as India's stakes are concerned, she need not go overboard or get carried away by the dictates of USA and others alike. She needs to keep in mind that the Korean crisis is largely created by the USA and its allies. Also, India needs to remember that superpower interventions in Asia have always been counterproductive, be it in the Gulf region, Afghanistan, Vietnam, or elsewhere. India should only be party to any constructive and peaceful approach in resolving the Korean crisis. India's pragmatic approach towards Afghanistan, though distinct from Korean theatre, could be considered as a good proposal. India's relatively quiet diplomatic steps involving Korean issues during the last couple of years may give an impression that "India is trying to quietly rebuild ties with the reclusive regime, ostracised by most of the world due to its defiance of UNSC norms on nuclear weapons" (Haidar, 2018). It is unclear "what's behind India's recent outreach to North Korea"(Pant, 2018). India can go the extra mile in brokering peace in the Korean peninsula and helping North Korea to economically stabilise, provided it opens up to the world positively discarding its nuclear jingoism. However, it is early to arrive at any conclusion as "North Korea can be highly unpredictable" (Ibid). India's cordial ties with South Korea, Japan and USA make it more sensitive and a delicate diplomatic issue to pay half-hazard attention. Moreover, the outcomes of the Korean crisis will have serious spillover effects on South and East Asia in which India cannot be a mute spectator. Therefore, any decision to enter the Korean fray should be taken with utmost caution and pragmatism.

\section{References}

BBC. (2010, May 20). 'North Korean torpedo' sank South's navy ship report. Retrieved from https://www.bbc.com/news/10129703

Bhattacherjee, K. (2016, June 24). India rejects charge on institute's ties with North Korea. Retrieved from https://www.thehindu.com/ news/national/India-rejects-charge-on-institute $\%$ E2\% $80 \% 99$ s-tieswith-North-Korea/article14397238.ece 
Bhowmick, N. (2018, June 21). India's embarrassing North Korean connection. Retrieved from https://www.aljazeera.com/ indepth/ features/2016/06/india-embarrassing-north-korean-connection160620195559208.html

Brands, H. (2018, May 30). How many U.S. troops are in Korea? Maybe too many. Retrieved from https://www.bloomberg.com/ view/ articles/2018-08-07/elon-musk-tweets-show-tesla-going-private-is-agood-idea

Davenport, K. (2018). The Six-Party talks at a glance. Arms Control. Retrieved from https://www.armscontrol.org/factsheets/6partytalks

Guangcheng, X. (2017). The Korean peninsula crisis and the role of Russia. Retrieved from http://valdaiclub.com/a/highlights/the-koreanpeninsula-crisis-and-the-role-of-russia/.

Haidar, S. (2018, May 16). V.K. Singh makes surprise visit to North Korea. Retrieved from https://www.thehindu.com/news/international/vksingh-makes-surprise-visit-to-north-korea/article23903652.ece

Kan, K. (2018, June 22). Is complete denuclearization of the Korean peninsula an unattainable goal? Retrieved from https:// www.nippon.com/ en/simpleview/?post_id $=47246$

Keating, J. (2017, September 29). China thinks the North Korea nuclear crisis is all America's fault. Retrieved from http:// www.slate.com/ blogs/the_slatest/2017/09/29/china_and_america_both_think_the_n orth_korea_crisis_is_the_other_country.html

Korda, M. (2018, July 6). Building trust on the Korean peninsula: The role of CBMs in nuclear negotiations. 38 NORTH. Retrieved from https://www.38north.org/2018/07/mkorda070618/

Landay J., \& Kalra, A. (2017, October 25). India defends ties with North Korea in talks with Tillerson. Retrieved from https://in.reuters.com/ article/tillerson-asia-india-northkorea/india-defends-ties-with-northkorea-in-talks-with-tillerson-idINKBN1CU0XZ

MEA. (2016, May 16). Visit of Minister of State for External Affairs General Dr. V.K. Singh (Retd.) to the Democratic People's Republic of Korea. Retrieved from https://mea.gov.in/press-releases.htm?dtl/29899/ Visit +of + Minister +of + State+for+ External+ Affairs+ General+ Dr+ $\mathrm{VK}+$ Singh+Retd+to+the+Democratic+Peoples+Republic+of+Korea

MEA. (2018). India-DPR Korea Relations. Retrieved from http://mea.gov.in/ Portal/ForeignRelation/ india_dprk_bilateral _ brief_for_mea_website.pdf

NDTV. (2017, August 12). 'India a loud voice, can help resolve N Korea crisis': Top US Commander. Retrieved from https:// www.ndtv.com/ 
world-news / india-can-help-defuse-north-korea-crisis-top-uscommander-1736856.

Objectiveias. (2018). North Korean Nuclear Crisis and India. Retrieved from http://www.objectiveias.in/North-Korean-nuclear-crisis-andindia/

Pant, H. V. (2018, May 22). What's behind India's recent outreach to North Korea? The Diplomat. Retrieved from https://thediplomat.com/ 2018/ 05/whats-behind-indias-recent-outreach-to-north-korea/

Perlez, J. (2017, September 5). U.S. desire for North Korea oil cutoff puts China in a tight spot. Retrieved from https://www.nytimes.com/ 2017/ 09/ 05/ world/asia/north-korea-china-us-oil-fuel-exports.html

PTI. (2017, December 20). India to be part of summit on North Korea's nuclear crisis. Retrieved from https:// www.thehindubusinessline.com/news/world/ india-to-be-part-ofsummit-on-north-koreas-nuclear-crisis/article9997693.ece

Ramesh, J. (2018, May 3). India's role in ending the Korean war. Retrieved from https://www.thehindu.com/opinion/op-ed/indiasrole- in-ending-the-korean-war/article23750989.ece

Reuters. (2012, March 30). Obama's outreach to North Korea. Retrieved from https://in.reuters.com/article/korea-north-usa-timeline/ timeline-obamas-outreach-to-north-korea-idINDEE82T07O20120330

Revolvy. (2010). Battle of Daecheong. Retrieved from https://www.revolvy.com/ page/ Battle-of-Daecheong

Roblin, S. (2018, April 16). A history of North Korea's nuclear nightmare. The National Interest. Retrieved from https:// nationalinterest.org/ blog/the-buzz/history-north-koreas-nuclear-nightmare-25367

Sajjanhar, A. (2017, December 4). North Korean nuclear crisis: What the world can do. Retrieved from https://www.orfonline.org/expertspeak/north-korean-nuclear-crisis-what-can-the-world-do/

Sinha, A. (2018, July 12). THAAD: The fear of China, anxiety of Russia. Retrieved from https:// economictimes.indiatimes.com/ news/ defence/thaad-the-fear-of-china-anxiety-of-russia/articleshow / 57273866.cms.

Stracqualursi, V., \& Collinson, S. (2018, June 13). Trump declares North Korea 'no longer a nuclear threat'. Retrieved from https:/ / edition.cnn.com/2018/06/13/politics/trump-north-koreanuclear-threat/index.html.

Strait Times. (2018, July 13). South Korea president Moon Jae-in seeks Asean's support for Korean peninsula peace process. Retrieved from https:/ / www.straitstimes.com/asia/east-asia/south-korean- 
president-moon-jae-in-seeks-aseans-support-of-korean-peninsulapeace

Terry, O. (2018, April 21). Is 'Denuclearization' the answer to the North Korea nuclear problem? The Diplomat. Retrieved from https://thediplomat.com/ 2018/04/is-denuclearization-the-answerto-the-north-korea-nuclear-problem/

The Crisis Group. (2018, January 23). The Korean Peninsula Crisis (I): In the Line of Fire and Fury". Retrieved from https:// www.crisisgroup.org/ asia/ north-east-asia/korean-peninsula/293korean-peninsula-crisis-i-line-fire-and-fury

The Economic Times. (2017, September 16). China says opposed to US nuclear weapons on Korean peninsula". Retrieved from https://economictimes.indiatimes.com/news/defence/china-saysopposed-to-us-nuclear-weapons-on-koreanpeninsula/articleshow/60712173.cms

The Indian Express. (2018, May 14). US vows to provide security assurance to North Korea's Kim Jong-un: Mike Pompeo. Retrieved from https://indianexpress.com/article/world/us-vows-to-providesecurity-assurance-to-north-koreas-kim-jong-un-mike-pompeo$5175900 /$

The Livemint. (2017, October 22). Rex Tillerson says India-North Korea ties could act as conduit for communications. Retrieved from https://www.livemint.com/Politics/zKlooN2PK9gdESwFhDLZCI/R ex-Tillerson-says-IndiaNorth-Korea-ties-could-act-as-condu.html

The New York Times. (2018, June 12). Trump-Kim Summit Ends With Promise to Suspend Military Exercise. Retrieved from https:/ / www.nytimes.com/2018/06/12/world/asia/trump-kimsummit.html

The Telegraph. (2010). North Korea bombs South Korea's Yeonpyeong Island. Retrieved from https://www.telegraph.co.uk/ news/ worldnews/ asia/ southkorea/8153000/North-Korea-bombs-SouthKoreas-Yeonpyeong -Island.html 23 Nov.

Vaddi, S. (2018). Singapore summit on North Korea's nuclear issue. Mainstream, LVI(29).

Waxman, O. B. (2018, July 26). The history behind the date chosen for the repatriation of Korean War Remains. Retrieved from http:// time.com/ 5343628/korean-war-armistice-remains/ 